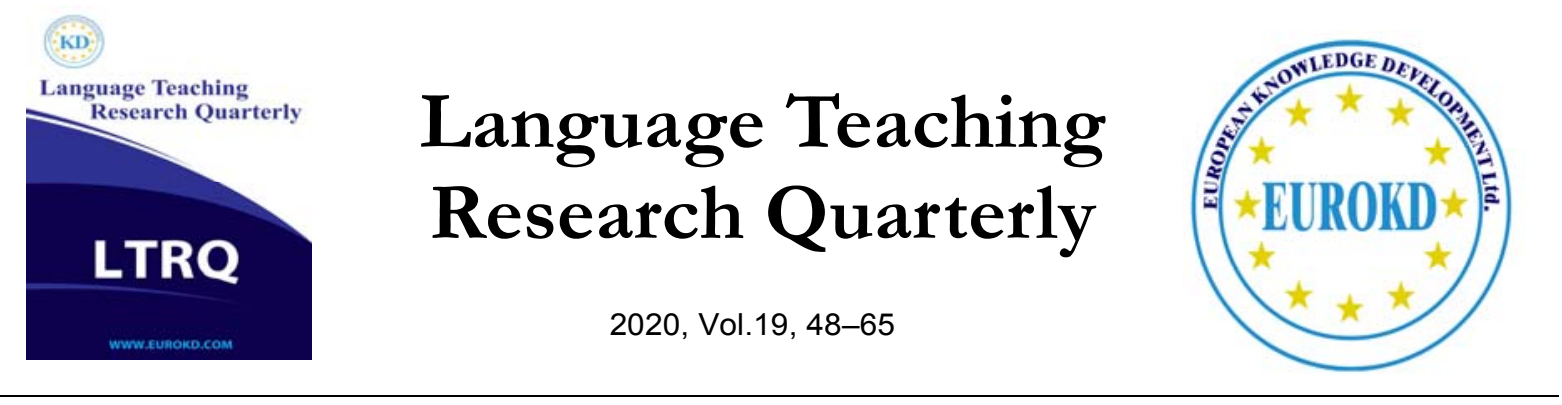

\title{
Promoting Advantageous Ways for Teachers and Learners to Deal with Corrective Feedback
}

\author{
Zohreh R. Eslami ${ }^{1, *}$, Ali Derakhshan ${ }^{2}$ \\ ${ }^{1}$ Department of Teaching, Learning and Culture, College of Education and Human Development, Texas A \\ \& M University, Texas, U.S.A. and Liberal Arts, Texas A\&M University-Qatar \\ ${ }^{2}$ Department of English Language and Literature, Faculty of Humanities and Social Sciences, Golestan \\ University, Gorgan, Iran
}

Special Issue: Pathways to the Successful Teaching and Learning of an L2

In Honor of Andrew Cohen's Contributions to L2 Teaching and Learning Research

Received 15 November 2019 Accepted 25 April 2020

\begin{abstract}
Researchers and educators in the field of second language acquisition (SLA) have long been interested in the role of corrective feedback (CF) in language teaching and learning (Cohen, 1975, 2018; Ellis, Loewen, \& Erlam, 2006). The main goal is to explore how to provide CF, the kind of feedback to provide, when, and by whom in order to facilitate learner's uptake and second language (L2) development (e.g., Carroll \& Swain, 1993; Han, 2002; Lyster \& Ranta, 1997). As Cohen (2018) states, aligned with more learner-centered approaches to language teaching, not only should teachers know how to deal with providing CF but they also need to promote learners' awareness as informed consumers of CF to optimize its effect in their L2 development journey with the highest level of efficiency (Cohen \& White, 2008). CF is defined as comments on accuracy or suitability of students' comprehension or production of a foreign/second language. The extent of CF and the ways in which learners can strategically embark on such CF is still open to debate due to the fact that there are many mediating factors influencing the efficacy of $\mathrm{CF}$. Consequently, being able to propose advantageous ways of providing $\mathrm{CF}$ by teachers and effective use of CF by learners in L2 education settings remains a desideratum which requires a systematic review of various aspects of $\mathrm{CF}$ and factors contributing to its effectiveness. To this end, the current
\end{abstract}


paper opens by providing a definition of $\mathrm{CF}$ and delineating how it is operationalized in different theoretical schemes. Categories of $\mathrm{CF}$ are described as are technology-based means for $\mathrm{CF}$, and key dilemmas regarding $\mathrm{CF}$ and its effectiveness are noted. The conclusion reached is that $\mathrm{CF}$ must be viewed as highly complex especially as it concerns learners' autonomy in L2 development and in effectively strategic use of CF. The article ends with some recommendations regarding advantageous ways of promoting CF practice in L2 classrooms.

Keywords: Corrective feedback, individual differences, interactional feedback, technology-based corrective feedback, complexity theory, learners' autonomy

\section{Introduction}

Corrective feedback (CF) has produced a huge amount of research in the past two and a half decades (e.g., Allwright, 1975; Cohen, 1975; Plonsky \& Brown, 2015-review article). Despite an abundance of research in this area, there is no easily operationalizable framework for CF that could be offered as a panacea for all L2 instructional settings. This is because L2 development is a dynamic process, often nonlinear and episodic, making static or linear metaphors of mastery or programmatic progression invalid (Schulze \& Smith, 2015).

As $\mathrm{CF}$ and its effectiveness is influenced by a large array of factors, including learner beliefs, motivation, external guidance, the learner's sense of self, metacognitive knowledge, and language learning history, we may need to use complexity theory (CT) also known as complex dynamic systems (Murray \& Lamb, 2018; Reinders \& White, 2016) to describe how to approach the CF construct strategically. Due to this complexity, advantageous ways of providing CF and benefiting from it can be recommended only after one has fully reviewed various aspects of $\mathrm{CF}$ and its effectiveness (Cohen, 2018).

\section{CF: Theoretical Relevance and Empirical Research}

The earliest works on CF were descriptive with an emphasis on recording and transcribing actual classes and identifying and classifying teacher corrections (Ellis, 2017). Previous research has explored various aspects of CF such as its overall effects (e.g., Oliver \& Mackey, 2003), the most effective types of CF (e.g., Chen, Nassaji, \& Liu, 2016), learners' perspectives toward CF (e.g., Li, 2017), and, more recently, comparison of CF in computer-mediated environments and face-to-face situations (e.g., Nassaji \& Kartchava, 2019; Ribeiro, Jiang, \& Eslami, 2019).

$\mathrm{CF}$ is allocated a very different role depending on the theoretical approach taken and the language teaching methods employed (Ur, 1996). An early behaviorist view was that errors were unacceptable and should be eradicated (Cohen, 1975). However, these behaviorists failed to explain why learners continued to make errors despite receiving $\mathrm{CF}$ and other interventions. Thus, Krashen (1985) proposed the monitor model, in his SLA theory (the Natural Approach), and ruled out the effectiveness of CF. Taking issue with Krashen's viewpoint, cognitive and sociocultural perspectives suggest that there are some benefits to be derived from CF in the SLA process (e.g., Dekeyser, 2003; Gass \& Mackey, 2006; Vygotsky, 1978). 
The cognitive-interactionist perspective has focused on the two dimensions of inputproviding/output-prompting and the implicit/explicit nature of CF on the ground that all types of $\mathrm{CF}$ are not equally effective and thus, the central goal of CF studies must be to uncover which CF types work best for language development (Chen et al., 2016). According to the sociocultural perspective, there is no such a thing as the best type of $\mathrm{CF}$, because for CF to be facilitative, it should be systematically adjusted to the learners' zone of proximal development (ZPD) (Ellis, 2012).

As a complex phenomenon, $\mathrm{CF}$ involves cognitive, social, and psychological dimensions and can be affected by varying factors, including learners' individual differences, interactional context, the nature of the target structure, CF explicitness/implicitness, and the duration of the CF intervention (Nassaji,2016; Storch, 2010). The cognitive dimension accounts for how learners process the information provided by $\mathrm{CF}$ for acquisition (i.e. the interactions between input, output and the learner's internal mechanisms). The social dimension, however, acknowledges that CF and learners' capacity to benefit from it are influenced by the social context in which it is enacted and by the social background of the participants. The psychological dimension addresses how individual variables such as beliefs about learning, language aptitude and anxiety impact both the teacher's choice of CF strategies and learners' responses to them. Accordingly, the interactionist-cognitive and sociocultural perspectives toward SLA address CF in alignment with their principles. As regards cognitive theories, CF works best when learners attend primarily to meaning as they engage in interactions, and receive $\mathrm{CF}$ regarding their errors (Chen, Lin, \& Jiang, 2016).

Sociocultural theory integrates the cognitive, social and psychological perspectives. Accordingly, language acquisition happens during collaborative interaction. Taking a sociocultural perspective, L2 learning happens when learners participate in social interactions and engage in collaborative learning activities. Successful interaction happens when the feedback provided to the learners is within their ZPD (Lantolf \& Zhang, 2017). In such situations, what might be considered as a useful type of $\mathrm{CF}$ for one learner might not work well for another because the provision of CF must be tailored to the learners' ZPD (Nassaji \& Swain, 2000).In other words, effective CF may well need to be flexible enough so that it caters to individual learners' needs in the given social and situational context. CF should also take into account the affective needs of the learners. Ultimately, it is the individual learners who determine whether to incorporate the $\mathrm{CF}$ into their language behavior.

As a multifaceted phenomenon, $\mathrm{CF}$ and its effectiveness are influenced by a large array of factors leading to some controversies and challenges in justifying the need for CF and its effectiveness in L2 language development. Before we discuss the dilemmas and challenges in dealing with controversies on the role of $\mathrm{CF}$ in L2 language acquisition, we first explain the main types of CF discussed in the literature. 


\section{Main Types of CF}

Although there might be some differences amongst SLA researchers and educators in how they classify CF, most of them agree on the main types of CF. Lyster and Ranta (1997), for example, identified six main types of CF strategies including explicit correction, recasts, clarification requests, metalinguistic comments, elicitation, and repetition. Explicit correction is a type of feedback by which the teacher points out the students' errors and then gives the correct forms. Recasts happen when the teacher repeats all parts of the learner's utterance but replaces the incorrect part with the correct form. Clarification requests are utilized in situations when the teacher wants in some way to show that what the learner has produced was incorrect or illformed. Metalinguistic feedback includes questions, information, or comments regarding the accuracy or appropriateness of the learner's production without explicitly providing the correct version. Elicitation happens when the teacher requests the learner to correct his/her production or employs a question to elicit the correct form. Finally, repetition pertains to the teacher's restatement of the learner's incorrect production with or without highlighting the incorrect form. These six CF categories can differ based on two characteristics: whether they are input-providing or output-prompting or whether they are implicit or explicit. Through input-providing CF, teachers may give the correct form to the learners, whereas in output-prompting $\mathrm{CF}$, they push students to correct their own erroneous utterances (self-correction). Moreover, in implicit CF, the corrective form is not provided to the students, while in explicit CF, the corrective form is clearly provided to them.

CF instances can also be distinguished based on whether they are highly focused, focused, or unfocused. Highly focused CF happens when only one error category or grammatical error is the target of the practice (Bitchener \& Knoch, 2009). Focused, selective, or intensive CF addresses only one or two types of error each time, while in unfocused, comprehensive, or extensive CF, the teacher addresses almost all the errors that the learners make. Another dimension through which CF can be classified is whether it is oral or written. Oral CF is mainly given in online speech production, while written $\mathrm{CF}$ is generally postponed after the completion of a written task.

As a result of task-based language learning approaches and interactionist views of Erin feedback has been emphasized and explained as the CF provided during interactions (see Nassaji, 2016 for a comprehensive review). Interactional feedback refers to "feedback generated implicitly or explicitly through negotiation and modification processes that occur during interaction to deal with communication or linguistic problems" (Nassaji, 2016, p. 536).

Substantiating the effectiveness of different types of CF in L2 development is among those issues still open to debate (Chen et al., 2016). It is partly because the efficacy of CF can be affected by multiple factors in a dynamic and complex fashion. Some of the controversies regarding the number of hard-to-resolve issues and the complex interaction between different factors related to $\mathrm{CF}$ are presented in the next section. 


\section{Dilemmas Regarding Corrective Feedback}

Some difficulties and hard-to-resolve issues regarding $\mathrm{CF}$ include questions such as: Does $\mathrm{CF}$ contribute to the efficacy of L2 acquisition? If so, when should learners' errors be corrected? Which learners' errors should be corrected? How should learners' errors be corrected? And who should correct learners' errors? (e.g., Ellis, 2008, 2012, 2017; Hendrickson, 1978).

Regarding the first question (the efficacy of $\mathrm{CF}$ ), different positions are taken by different theoretical approaches and teaching methods (Ellis, 2008, 2012). For instance, while correction is regarded as unwelcome in humanistic methods, it is considered as a requirement in the Audiolingual method. Moreover, researchers (e.g., Allwright, 1975; Cohen, 1975, 2018) recommend that whether an error should be corrected or not depends on the characteristics of the learners, how important the correction is, the ease of correction, the frequency of the error, the level of generality of the error, the potential effects of the error, the nature of teacher correction, and the adequacy of teacher's knowledge about and skill in handling the error correction.

In his seminal work, Truscott (1996) contended that grammar correction in L2 classes is not only detrimental but also ineffective. This postulation led to a long-standing debate which has galvanized many researchers ever since. According to Truscott (1996, 1999), correcting learners' errors in a written composition would possibly enable them to eliminate the errors in a subsequent draft, but would have no effect on grammatical accuracy in a new piece of writing. Ferris (1999), however, stated that if the correction were clear and consistent, it would be effective and would transfer to future correct use of the form. As Hyland and Hyland (2006) asserted, "it is difficult to draw any clear conclusions and generalizations from the literature as a result of varied populations, treatments and research designs" (p. 84).

Concerning the efficacy of oral CF, Krashen (1982) fervently asserted that correcting learners' errors was a serious mistake because it would put pressure on learners, and it could only facilitate the process of learned knowledge development not acquired knowledge. From an interactionist perspective, Long (1996) mentioned that if oral CF were provided as an opportunity for the negotiation of meaning, it could help acquisition through aiding learners to notice their errors and create form-meaning connections. Lyster and Saito (2010) also expressed the view that in comparison to adults, children gained more advantages from implicit oral $\mathrm{CF}$ as it assisted them in their implicit learning, in that it was more consistent with their learning processes.

The abundance of empirical research undertakings regarding CF from the last decade of the $20^{\text {th }}$ century onward has led to several meta-analysis studies on this issue (e.g., Anderson, 2011; Brown, 2016; Li, 2010; Li \& Vuono, 2019; Lyster \& Saito, 2010; Yousefi \& Nassaji, 2019). In general, most of these studies have acknowledged the beneficial effect of CF for language acquisition. Li's (2010) meta-analysis study, for example, included 33 studies on oral CF. The findings of this meta-analysis revealed that $\mathrm{CF}$ has a moderate effect on language acquisition. Furthermore, the findings showed that $\mathrm{CF}$ could facilitate gains in both implicit and explicit knowledge as it proved effective in tests measuring free production and controlled language use. Anderson's (2011) systematic review of studies on the efficacy of CF on L2 acquisition provided 
research evidence that selective written feedback was preferable to comprehensive CF in that it was more likely to be beneficial.

In general, SLA studies of CF afford plenty of evidence for the efficacy of oral CF (e.g., Han, 2002; Lyster, 2004; Sheen, 2006) as well as written CF (e.g., Bitchener, Young, \&Cameron, 2005; Ferris, 2006; Sheen, 2007; Shintani \& Ellis, 2013). These studies have indicated that when $\mathrm{CF}$ is consistent, clear, and focused, it promotes language acquisition. However, Storch's (2010) critical review of early research on written CF revealed that although these studies supported the efficacy of written $\mathrm{CF}$, there were inherent flaws in them which included the lack of a control group, the utilization of revised not original texts, the use of unsuitable writing tasks, the lack of comparability, and problems in the accuracy of measurement. Future studies need to use more rigorous research designs to be able to provide us with more robust findings.

As far as interactional feedback is concerned, studies such as that by Nassaji (2011) have examined the relationship between immediate student repair (uptake) as a consequence of interactional feedback and attainment of linguistic forms. In a study of Chinese adults as foreign language learners, Fu and Nassaji (2016) investigated the effectiveness of the instructor's interactional feedback while putting emphasis on learner uptake. The effectiveness of learner uptake on language development was associated with feedback explicitness. Likewise, Bell (2005), in an experimental study, compared the effectiveness of elicitation, recasts, and elicitation plus recasts on the ability of learners in ESL classroom contexts to formulate questions. The results of the study indicated that regarding short-term gains, recasts were found to be the most effective feedback type, but recasts in combination with elicitation contributed more to learners' long-term gains.

As can be seen from the brief discussion above, although most of the research studies have provided evidence regarding the efficacy of CF in L2 acquisition, in order to be able to provide clear guidelines for teachers and learners, we need to address factors which interact in complex ways and might influence the effectiveness of CF. On the one hand, there are the situational dimensions of $\mathrm{CF}$, such as the timing of $\mathrm{CF}$, who initiates it and whether it is a joint effort, the type of CF selected, and the modality of the CF. On the other, there is the issue of individual differences among learners as well as cultural differences, especially since certain kinds of $\mathrm{CF}$ are inappropriate in certain cultural situations.

As it relates to CF timing, there is a relative agreement among researchers that immediate $\mathrm{CF}$ is preferable when one targets accuracy, while delayed CF is more promising when the focus is on fluency (Scrivener, 2005). However, Doughty (2001) posited that in order to induce change in learners' interlanguage, CF needed to take place in a timely manner that attracted the learners' attention to form while their focal attention remained on meaning. Doughty (2001) suggested that delayed CF which called for focal attention on form resulted primarily in explicit rather than implicit L2 knowledge. In other words, the learners might function well on a grammar test but might very well not use the appropriate grammatical forms when focusing on meaning.

The potential justification for delaying correction in fluency work is that correction puts students under pressure and gets in the way of students' attempt to communicate. In response to 
this view, Ellis, Basturkmen, and Loewen (2001) asserted that there was not sufficient research evidence to make the assumption that immediate CF word unavoidably interfered with the process of fluency practice. Two decades later it would still appear that research has not provided us clear guidelines as to the effectiveness of immediate versus delayed CF.

Regarding the third question, there is no unanimous decision about the kinds of errors that need to be corrected. A related question is whether CF should be given for all or most of the errors learners make (unfocused) or whether it should address just one or more error types (focused).

Corder (1967) made a distinction between mistakes, which are performance slips, and errors, which are deviations resulting from gaps in competence. Most researchers agree that learners should be corrected for their errors not for their mistakes. Alternatively, Burt (1975) recommended focusing on learners' global errors (e.g., overall sentence organization) and disregarding local errors (e.g., single elements in a sentence). However, it is sometimes a challenge for teachers to distinguish whether a deviation is a mistake or an error or whether it is local or global.

Another question related to which errors to correct is whether CF should address all or most of errors learners make (unfocused) or address just one or two error types (focused). Language educators tend to support the position that focused and selective CF works best and have warned that teachers should not over-correct errors, because "learners can only use just so much feedback information: to give too much may simply distract, discourage and actually detract from the value of learning" (Ur, 1996, p. 255). Anderson's (2011) systematic review of comprehensive and selective feedback for writing strategies in the ESL/EFL classroom context provided evidence that selective rather than comprehensive written feedback (e.g. targeting definite articles) is preferable in that it produces more tangible results. Hence, focused CF on specific errors is deemed to lead to more desirable outcome. As Krashen (1982) claimed, error correction should be limited only to features which are simple and portable. Similarly, Ferris(1999) suggested providing direct written CF with regard to treatable errors involving features that are patterned and rule-governed. Researchers concur that empirical evidence regarding the efficacy of grammar correction is scarce and incomplete, and that further studies are needed to be able to provide more conclusive findings

The question of how learners' errors should be corrected led to the emergence of extensive research on how to determine the most effective strategies to be used for error correction. This dilemma has been a lingering issue as researchers still have not been able to provide a conclusive answer to the question of what is the best way to correct learners' errors (Ellis, 2012).

Language educators and SLA researchers have identified a number of variables mediating CF provision, and different strategies to use for correction. One issue to consider is whether we are dealing with written CF or oral CF (see Li \& Vuono 2019 for a review study). In written CF a key issue is the distinction between direct and indirect forms of correction, whereas in oral $\mathrm{CF}$ the concerns are whether to provide explicit or implicit and whether the CF is input-providing or output-prompting. Input-providing CF types include recasts and explicit correction of the error. 
Output-prompting CF types include repetition, clarification requests, metalinguistic explanation, elicitation, and paralinguistic signals. Some empirical research has confirmed that prompts are more facilitative than recasts (e.g., Yang \& Lyster, 2010). However, the results of some other studies (e.g., Nassaji, 2017) gave credence to the superiority of recasts, while nonetheless pointing out that whether a recast is effective is a complex matter and that there are mediating factors such as how the recasts are delivered to the given learners. Conversely, Rezaei and Derakhshan (2011) reported that metalinguistic feedback was more beneficial than recasts when teaching conditional sentences. Moreover, some studies have compared the efficacy of implicit and explicit CF. Li's (2010) meta-analysis study revealed that, in general, explicit CF seems to be more effective in the short term, but that delayed post-test scores would suggest that implicit $\mathrm{CF}$ is more beneficial for long-term gains.

It was recently suggested by Professor Cohen (Personal Communication, March, 2020) that the complexity of CF might best be depicted through a three-dimensional model. A twodimensional continuum of explicit-implicit seems to be inadequate to capture a construct as complex as $\mathrm{CF}$, with numerous factors playing a role in its effectiveness for language learning. Besides, if teachers were to conduct close-order observation of just how complex learners' moment-by-moment strategizing is in their language performance, they would probably come away with a better understanding of what it means to provide CF that is appropriate for the given student with regard to the given error (Cohen \& Wang, 2018a, 2018b). In the best of all possible worlds, teachers' CF reflects informed attempts to cater to individual differences among their students (Allwright, 1975; Ellis, 2009, 2017; Nassaji, 2016, 2017).

SLA researchers have different claims about the strategies to use for CF depending on their theoretical perspective. Long (1996), using interactionist perspective, for example, opined that $\mathrm{CF}$ such as recasts should provide learners with the correct target forms in a context that establishes form-meaning connections without interfering with the flow of communication. Lyster (2004), based on output hypothesis, claimed that output-prompting strategies were preferable because they enabled learners to enhance control over linguistic forms that they had not fully acquired. Seedhouse (2004), however, claimed that direct, unmitigated repair by the teacher should be preferred to recasts as it is quick and non-embarrassing. Based on a review of CF studies, Ellis et al. (2006) maintained that even though both implicit and explicit CF could support acquisition, explicit CF would generally be more effective than implicit CF. In a metaanalysis study, Russell and Spada (2006) confirmed that CF was effective in promoting acquisition but that due to insufficient number of studies meeting the requirements of a metaanalysis, they were not able to show which strategy was the most effective. SLA research findings indicate that the most effective strategy for CF is a mute question because, as noted above, contextual, situational, and individual differences among learners all play a role in complex ways, and thus a one-size-fits-all solution does not exist.

Finally, as to the last question, who should correct errors, the three possible answers are the teacher, the learner who made the error, or peers (Ellis, 2012). Some researchers argue that instructors should first provide learners with opportunities to self-correct. If learners fail to do so, 
then peers should be invited to intervene and provide correct forms. In the case that peer feedback does not work, as the last resort teachers could provide feedback to learners (Scrivener, 2005). Along the same lines, Cohen (1975) maintained that teacher correction alone was not likely to bring about extensive changes in learners' interlanguage development - that learner self-correction and peer correction could be more facilitative in many instances than teacher correction. This statement was also corroborated by Ferris (2006) who maintained that urging students to self-correct plays a facilitative role in language acquisition. Other researchers have focused on identifying the most effective CF types in terms of learner self-correction or repair following CF. For instance, Lyster and Ranta (1997) reported that learners were more likely to correct their lexical and grammatical errors after they received metalinguistic cues, requests for clarification, and elicitations. Similarly, Lyster and Ranta (2013) maintained that if teachers included the negotiated form in their CF in a way that resulted in learner uptake and self-repair, this process could lead to acquisition in that it would result in deeper processing. The researchers argued that a valuable teaching strategy would be to increase participatory demands on students by using CF types that pushed them to modify their output.

So, we can see that more recent thinking about CF transfers some of the responsibility to the learners themselves, whereas the earlier writings on CF (e.g., Allwright, 1975) had tended to put the burden of providing CF on the shoulders of teachers. It was initially felt that teachers were the main source of information regarding L2 in the classroom, and that they should react to learners' errors whenever they felt it was appropriate to do so. In support of this earlier teacheras-provider-of-CF position, a caveat here is that age can be an intervening factor since young learners may not be developmentally ready to receive grammatical rules by means of correction. As stated by Cohen (1975), children under seven years old may not gain any advantage when an adult corrects their linguistic errors as under the age of seven, children are not developmentally ready to receive grammatical rules by means of correction (Ervin-Tripp, 1974). We should also consider learners' preference in error correction (self-correction, peer-correction, teachercorrection), and their level of competence to be able to correct their own errors and the challenges associated with lack of clarity in indirect CF to make learners understand the nature of the problem (linguistic or communicative).

\section{Technology-Mediated Corrective Feedback}

Recently, a new surge of research has focused on comparing the effectiveness of CF in face-toface and computer mediated communication (SCMC) situations (e.g., Nassaji \& Kartchava, 2019; Ribeiro et al., 2019). The extensive research done in this area needs its own review and is beyond the scope of this study. Nassaji and Kartchava (2019) provide an overview of the most recent findings on technology-mediated feedback and instruction in their editorial on the special issue of International Journal of Applied Linguistics. The literature on CF and its effects in CMC environments shows mixed results. To elaborate on one of such studies, Ribeiro et al. (2019) examined potential differences which may exist between text-SCMC and face-to-face interactions pertaining to $\mathrm{CF}$. Their results indicated that in text-SCMC interactions, more 
attention was paid to form, and in face-to-face interactions, focus was more on negotiation of meaning. Therefore, the authors concluded that $\mathrm{CF}$ types that the two groups used were related to the mode of interaction, and both modes were advantageous for learners' interlanguage development. Overall, the results from $\mathrm{CF}$ studies in $\mathrm{CMC}$ suggest that recasts and metalinguistic information are the most frequent CF types available in CMC. Since most of the research is conducted in instructional settings adopting an experimental or quasi-experimental design, extreme caution has to be exercised in any attempt to extend findings from these studies to naturalistic $\mathrm{CMC}$ environments.

\section{Discussion}

For over forty years, researchers have devoted much time and effort to finding the best way to correct learners' L2 errors (Cohen, 1975). The intention of such an undertaking was to arrive at a systematic way for judiciously correcting L2 errors. This simplistic view of CF disregarded the fact that due to the complexity of factors mediating the efficacy of CF in L2/FL classrooms, there can be no single panacea for remedying all learners' errors in all learning situations. Recently, however, backboned by interactionist-cognitive and socio-cultural theories of SLA, the focus on finding the best way to correct errors has been downplayed based on the rationale that the same type of CF may be practiced very differently in differing situations (Cohen, 2018). Bitchener and Ferris (2012) propound that it is simplistic to attach a "one-size-fits-all" label to the study of $\mathrm{CF}$, and teachers need to collaborate with their students to discover which feedback approaches are most suitable for the learners rather than imperiously determining what is or is not appropriate for them. Therefore, various researchers have shifted their attention from finding the best way to correct errors to promoting learner strategies for deriving benefit from explicit attention to errors in different situations.

The goal of the current paper was to promote advantageous ways for learners to deal with error correction. As stated by Ellis (2010), CF is such a complex phenomenon that any error correction policy must bring all cognitive, social, and psychological dimensions into light. Therefore, in line with what Ellis (2010) advocated, this paper ends with the conclusion that in order to arrive at sound recommendations as to CF that learners will benefit, language educators need to take into account just how complex the provision of CF actually is and the role that different factors might play in its effectiveness in a given situation. In the following section, some suggestions are put forward to raise teachers' awareness of CF and factors mediating its effectiveness. Following that, we provide some insights as to how learners can strategically gain from $\mathrm{CF}$ provided to them in L2 classrooms.

\section{Suggestions for Classroom Instructors}

It is beneficial if teachers consider the cultural background of the learners when they want to correct errors. For example, public correction of error may not work for learners coming from a cultural background in which they only publicly perform a new skill after they have fully perfected it in private (Cohen, 1975). Besides, in line with the fact that at this era of globalization 
learners are considered as digital natives who consider technology to be an integral part of their life, it is recommended that more $\mathrm{CF}$ be provided to L2 learners in technology-based communication environments (Ribeiro et al., 2019).

Moreover, in line with Ellis's (2010) broader perspective toward CF, besides consideration of various cognitive and social factors for $\mathrm{CF}$ provision, teachers should also focus on learnerinternal factors which may drastically affect CF outcomes. Such learner individual differences include, but are not limited to, language anxiety, learning styles, working memory, language aptitude, and conceptions of learning. Quite on a par with Ellis $(2010,2013)$, other researchers (e.g., Bitchener \& Ferris, 2010; Bitchener \& Storch, 2016) have stipulated that individual variables such as gender, age, learning styles, motivation, external and internal factors, including diverse ethnic/subgroups' L1s can play pivotal roles in CF. In addition, learners' beliefs, attitudes, and perceptions toward and preferences for CF play decisive roles in CF effectiveness (Ferris, 1995; Li, 2017).

Teachers can play a pivotal role in promoting learners to engage their own identities and interests in language lessons and promote a sense of continuity between what they learn and do in the classroom, and who they are and what they are interested in doing in their lives outside the classroom, now and in the future (Cohen 1975; Ushioda, 2011). As Silva (2018) submits, in order to enhance students' options of becoming autonomous, language learning contexts should offer different opportunities aligned with different students' identities by providing them with a wide variety of activities, from which they will choose the ones that they feel attracted to and that will give them a sense of language as it is used in the real world.

\section{Suggestions for Language Learners}

With new opportunities for autonomous language learning through mobile devices and other authentic materials in the target language and with the rise of informal language learning online, learner's autonomy and agency in language learning has become more important (Cohen \& White, 2008; Godwin-Jones, 2019). The growing emphasis placed on social factors in recent years has led to autonomy being studied with emphasis on multiple and intertwined connections among users, tools, artifacts, and settings, including cultural and educational contexts. As a result, research has moved away from understanding autonomy as self-paced individualized learning to viewing it in a social context (Benson, 2001, 2006).

The choice of learning resources is wide and personal, but inevitably draws the learner into contact — and into learning opportunities — with fellow learners and native speakers. In the digital world, learners have several diverse tools such as media, and online communities (Cohen \& Pinilla-Herrera, 2010). Studies of learner motivation are linked to how much effort the learners invest in their language learning and to the various ways that they strategize with regard to incorporating CF in this effort (Cohen, 2005, 2010, and 2018). As is the case, in informal and online language learning, there are a number of materials and methods to choose from. The effectiveness of the resources depends on the learner in question (Cohen \& Wang, 2018a, 2018b), so that strategies for using CF will depend on where the learner is in the development 
process and how that new element interacts with other components (i.e., level of difficulty, ability to customize through glossing or subtitling, etc.). Increasingly, this is seen as a process of self-regulation (Cohen \& Wang, 2018a, 2018b), in which successful learners will have the willingness and ability to "reassess, revise, restart, reinvent" (Moyer, 2017, p. 401) when encountering new learning options. Self-regulation involves learners being active participants in their own learning (Rose, Briggs, Boggs, Sergio, \& Ivanova-Slavianskaia, 2018).

The cultural context in which L2 development takes place - including national cultures, institutional cultures, and the culture of online discourse communities - plays an important role in how learners perceive and process CF (Chik, 2018). What exactly constitutes the intensity and level of learner's autonomy can be a reflection of Western versus non-Western cultures (Oxford, 2017).

Writing a personal language learning history/diary can be an illuminating experience, making learners conscious of their stages in this development journey, as well as creating a general awareness of language and language learning (Benson \& Chik, 2010, Cohen, 2018). The selfreflection involved can lead to critical language awareness. Cohen (2018) as a successful polyglot and highly achieved language learner (Chinese being his $13^{\text {th }}$ language) shares his research-supported insights for successful language learning. One of the ideas he shares is journaling about all aspects of his mental and physical life during the language learning process. Cohen's insights reveal how individual and social forces influenced his language learning experiences. As Cohen (2018) submits, his development in multiple languages was enhanced by language awareness and self-reflection.

Language learning is complex, embracing cognitive and social aspects as well as the pedagogical and sociopolitical contexts (Zhang, 2016). In analyzing L2 development in general and $\mathrm{CF}$ in particular, this complexity is often reduced to studying individual components of the construct. With such complex systems, simplification decontextualizes and distorts the dynamic process at work (Godwin-Jones, 2019). Complexity theory promotes moving beyond binary opposites, and looking for reciprocal relationships, rather than relying on a cause-and-effect model (Godwin-Jones, 2019; Murray \& Lamb, 2018). The array of factors mediating the effectiveness of CF in the SLA process is shown in Figure 1. 


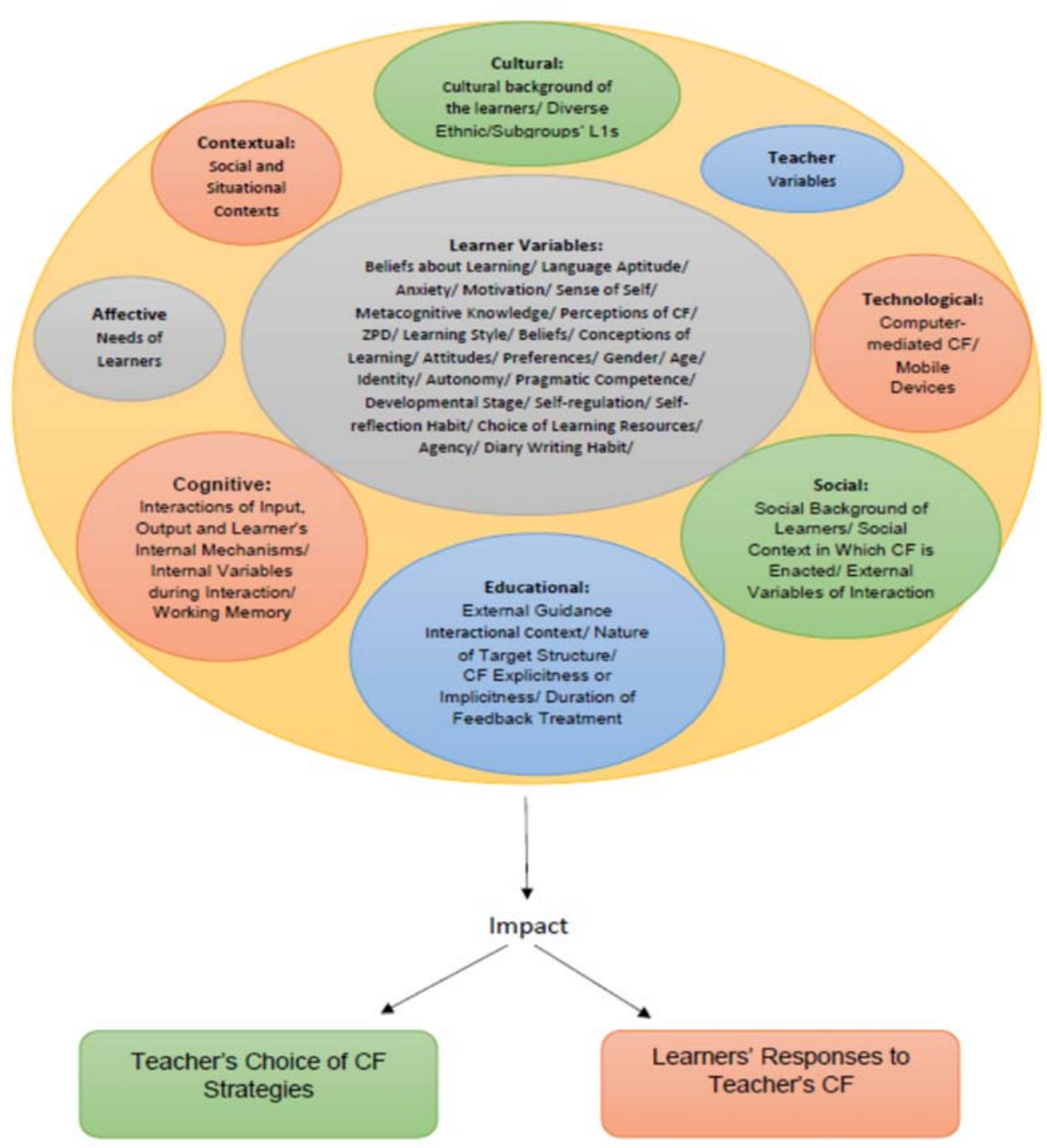

Figure 1. Array of Factors Mediating the Effectiveness of CF in the SLA Process

\section{Suggestions for Future Research}

An avenue for research which has not yet reached conclusive results pertains to the effects of CF among monolinguals, bilinguals, and multilinguals (Cohen, 1994, 2014).Language backgrounds and ethnicities undoubtedly play a crucial role in the CF choices the teachers make in a multilingual classroom, where their awareness as to the peculiarities of language transfer and socio-cultural differences that are likely to arise may be crucial.

Another fruitful research area requiring more widespread attention is the effect of $\mathrm{CF}$ on learners' L2 pragmatic competence development which still remains a desideratum. Therefore, future studies could enrich the current body of research (e.g., Nipaspong \& Chinokul, 2008; Salemi, Rabiee, \& Ketabi, 2012; Shirkhani \& Tajeddin, 2017; Yousefi \& Nassaji, 2019) on this 
issue in order to arrive at more solid findings. Furthermore, length and duration of CF are influential factors which need to be revisited. Recent research efforts have tended to entail "oneshot" designs with only a short interval between the intervention and taking the posttest or delayed posttest; nonetheless, "language learning requires extensive and sustained meaningful exposure and practice" (Storch, 2010, p. 42), so more longitudinal research is needed. In short, enlightened use of CF in L2 classrooms calls for a thorough re-examination of the myriad of variables dealing with cognitive, social, and psychological factors potentially impacting the effect of CF in a given situation.

\section{References}

Allwright, R. (1975). Problems in the study of language teacher's treatment of error. In M. Burt \& H. Dulay (Eds.), On TESOL '75: New directions in second-language learning, teaching and bilingual education. Washington, DC: TESOL.

Anderson, A. (2011). Comprehensive or selective feedback, that is the question A Literature Review Focusing on Writing Strategies in an EFL/ESL Classroom. Universitet Goteborgs: Ämneslärarprogramet.

Bell, A. (2005). Interactional feedback and ESL question development (Unpublished M.A. Thesis). British Colombia, Canada: University of Victoria.

Benson, P. (2001). Teaching and researching autonomy in language learning. London: Longman.

Benson, P. (2006). Autonomy in language teaching and learning. State-of-the-art Article. Language Teaching, 40(1), 21-40.

Benson, P., \& Chik, A. (2010). New literacies and autonomy in foreign language learning. In M. J. Luzon, N. RuizMadrid, \& L. Villanueva (Eds.), Digital genres, new literacies and autonomy in language learning (pp. 63-80). New York, NY: Cambridge Scholar Press.

Bitchener, J., \& Ferris, D. R. (2012). Written corrective feedback in second language acquisition and writing. New York, NY: Routledge.

Bitchener, J., \& Knoch, U. (2009). The value of a focused approach to written corrective feedback. ELT Journal, 63(3), 204-211.

Bitchener, J., \& Storch, N. (2016). Written corrective feedback for L2 development. Multilingual Matters. Bristol/Buffalo.

Bitchener, J., Young, S., \& Cameron, D. (2005). The effect of different types of corrective feedback on ESL student writing. Journal of Second Language Writing, 14(3), 191-205.

Brown, D. (2016). The type and linguistic foci of oral corrective feedback in the L2 classroom: A meta-analysis. Language Teaching Research, 20(4), 436-458.

Burt, M. K. (1975). Error analysis in the adult EFL classroom. TESOL Quarterly, 9(1), 53-63.

Carroll, S., \& Swain, M. (1993). Explicit and implicit negative feedback: An empirical study of the learning of linguistic generalizations. Studies in Second Language Acquisition, 15(3), 357-386.

Chen, J., Lin, J., \& Jiang, L. (2016). Corrective feedback in SLA: Theoretical relevance and empirical research. English Language Teaching, 9(11), 85-94.

Chen, S., Nassaji, H., \& Liu, Q. (2016). EFL learners' perceptions and preferences of written corrective feedback: a case study of university students from Mainland China. Asian-Pacific Journal of Second and Foreign Language Education, 1(1), 1-5.

Chik, A. (2018). Beliefs and practices of foreign language learning: A visual analysis. Applied Linguistics Review, 9(2-3), 307-331. 
Cohen, A. D. (1975). Error correction and the training of language teachers. The Modern Language Journal, 59(8), 414-422.

Cohen, A. D. (1994). The language used to perform cognitive operations during full-immersion math tasks. Language Testing, 11(2), 171-195.

Cohen, A. D. (2005). Strategies for learning and performing L2 speech acts. Intercultural Pragmatics, 2(3), 275301.

Cohen, A. D. (2010). Focus on the language learner: Styles, strategies, and motivation. In N. Schmitt (Ed.), An introduction to applied linguistics (2nd ed., pp. 161-178). London, England: Hodder Education.

Cohen, A. D. (2014). Strategies for the super-multilingual in an increasingly global world. In B. Spolsky, O. InbarLourie, \& M. Tannenbaum (Eds.), Challenges for language education and policy: Making space for people (pp. 270-280). Abingdon, NY: Routledge.

Cohen, A. D. (2018). Reflections on a career in second language studies: Promising pathways for future research. $L 2$ Journal, 10(1), 1-19.

Cohen, A. D., \& Pinilla-Herrera, A. (2010). Communicating grammatically: Constructing a learner strategies website for Spanish. In T. Kao \& Y. Lin (Eds.), A new look at language teaching and testing: English as a subject and vehicle (pp. 63-83). Taipei, Taiwan: The Language Training \& Testing Center.

Cohen, A. D., \& Wang, I. K.-H. (2018a). Corrigendum to "Fluctuation in the functions of language learner strategies" [System 74C (2018) 169-182], System 78, 256-265.

Cohen, A. D., \& Wang, I. K.-H. (2018b). Fluctuation in the functions of language learner strategies. System, 74, 169-182.

Cohen, A. D., \& White, C. (2008). Language learners as informed consumers of language instruction. In A. Stavans \& I. Kupferberg (Eds.), Studies in language and language education: Essays in honor of Elite Olshtain (pp. 185-205). Jerusalem, Israel: The Hebrew University Magnes Press.

Corder, S. P. (1967). The significance of learners' errors. International Review of Applied Linguistics, 5(1-4), 161169.

DeKeyser, R. M. (2003). Implicit and explicit learning. In C. J. Doughty \& M. H. Long (Eds.), The handbook of second language acquisition (pp. 313-48). Oxford: Blackwell.

Doughty, C. (2001). Cognitive underpinnings of focus on form. In P. Robinson (Ed.), Cognition andsecond language instruction (pp. 206-57). Cambridge: Cambridge University Press.

Ellis, R. (2006). Researching the effects of form-focused instruction on L2 acquisition. AILA Review, 19(1), 18-41.

Ellis, R. (2008). The study of second language acquisition. Oxford, UK: Oxford University Press.

Ellis, R. (2009). A typology of written corrective feedback types. ELT Journal, 63(2), 97-107.

Ellis, R. (2010). Cognitive, social, and psychological dimensions of corrective feedback. In R. Batstone (Ed.), Sociocognitive perspectives on language use and language learning, (pp. 151-65). Oxford, UK: Oxford University Press

Ellis, R. (2012). Language teaching research \& language pedagogy. Malden, MA: Wiley Blackwell.

Ellis, R. (2013). Corrective feedback in teacher guides and SLA. Iranian Journal of Language Teaching Research, 1(3), 1-18.

Ellis, R. (2017). Oral corrective feedback in language teaching: A historical perspective. Avances En Educación Y Humanidades, 2(2), 7-22.

Ellis, R., Basturkmen, H., \& Loewen, S. (2001). Preemptive focus on form in the ESL classroom. TESOL Quarterly, 35(3), 407-432.

Ellis, R., Loewen, S., \& Erlam, R. (2006). Implicit and explicit corrective feedback and the acquisition of L2 grammar. Studies in Second Language Acquisition, 28(2), 339-368. 
Ervin-Tripp, S. (1974). Is second language learning like the first? TESOL Quarterly, 8(1), 111-127.

Ferris, D. R. (1995). Student reactions to teacher response in multiple-draft composition classrooms. TESOL Quarterly, 29(1), 33-53.

Ferris, D. (1999). The case for grammar correction in L2 writing classes: A response to Truscott (1996). Journal of Second Language Writing, 8(1), 1-10

Ferris, D. R. (2006). Does error feedback help student writers? New evidence on the short- and long-term effects of written error correction. In K. Hyland \& F. Hyland (Eds.), Feedback in second language writing: Contexts and issues, (pp. 81-104). Cambridge, MA: Cambridge University Press.

Ferris, D. R. (2011). Treatment of error in second language student writing (2nd ed.), Ann Arbor: University of Michigan Press.

Gass, S. M., \& Mackey, A. (2006). Input, interaction and output: An overview. AILA Review, 19(1), 3-17.

Godwin-Jones, R. (2019). Riding the digital wilds: Learner autonomy and informal language learning. Language Learning \& Technology, 23(1), 8-25.

Han, Z. H. (2002). Rethinking the role of corrective feedback in communicative language teaching. RELC Journal, 33(1), 1-34.

Hendrickson, J. (1978). Error correction in foreign language teaching: Recent theory, research and practice. Modern Language Journal, 62(8), 387-98.

Hyland, F., \& Hyland, K. (2006). Feedback on second language students' writing. Language Teaching, 39(2), 83101.

Krashen, S. (1982). Newmark's "Ignorance Hypothesis" and current second language acquisition theory. Unpublished manuscript.

Krashen, S.D. (1985). The input hypothesis: Issues and implications. New York, NY, Longman.

Lantolf, J. P., \& Zhang, X. (2017). Concept-based language instruction. In The Routledge handbook of instructed second language acquisition (pp. 146-165). Taylor and Francis.

Li, S. (2010). The effectiveness of corrective feedback in SLA: A meta-analysis. Language Learning, 60(2), 309365 .

Li, S. (2017). Teacher and learner beliefs about corrective feedback. In H. Nassaji \& E. Kartchava (Eds.), Corrective feedback in second language teaching and learning (pp. 143-157). New York, NY: Routledge.

Li, S., \& Vuono, A. (2019). Twenty-five years of research on oral and written corrective feedback in System. System 84, 93-109.

Long, M. (1996). The role of linguistic environment in second language acquisition. In W. C. Ritchie \& B. K. Bahtia (Eds.), Handbook of second language acquisition (pp. 413-468). New York, NY: Academic Press.

Lyster, R. (2004). Differential effects of prompts and recasts in form-focused instruction. Studies in Second Language Acquisition, 26(3), 399-432.

Lyster, R., \& Ranta, L. (1997). Corrective feedback and learner uptake: Negotiation of form in communicative classrooms. Studies in Second Language Acquisition, 19(1), 37-66.

Lyster, R., \& Ranta, L. (2013). Counterpoint piece: The case for variety in corrective feedback research. Studies in Second Language Acquisition, 35(1), 167-184.

Lyster, R., \& Saito, K. (2010). Oral feedback in classroom SLA: A meta-analysis. Studies in Second Language Acquisition, 32(2), 265-302.

Moyer, A. (2017). Autonomy in second language phonology: Choice vs. limits. Language Teaching, 50(3), 395-411.

Murray, G., \& Lamb, T. (2018). Space, place, autonomy, and the road not yet taken. In G. Murray \& T. Lamb (Eds.), Space, place, and autonomy in language learning (pp. 249-262). New York, NY: Routledge. 
Nassaji, H. (2011). Immediate learner repair and its relationship with learning targeted forms in dyadic interaction. System, 39(1), 17-29.

Nassaji, H. (2016). Anniversary article Interactional feedback in second language teaching and learning: A synthesis and analysis of current research. Language Teaching Research, 20(4), 535-562.

Nassaji, H. (2017). The effectiveness of extensive versus intensive recasts for learning L2 grammar. The Modern Language Journal, 101(2), 353-368.

Nassaji, H., \& Kartchava, E. (2019). Technology-mediated feedback and instruction. Special issue of International Journal of Applied Linguistics, 170(2), 151-153.

Nassaji, H., \& Swain, M. (2000). Vygotskian perspective on corrective feedback in L2: The effect of random versus negotiated help on the learning of English articles. Language Awareness, 9(1), 34-51.

Nipaspong, P., \& Chinokul, S. (2008). The effects of corrective feedback techniques on EFL learners' pragmatic production and confidence. PASSA, 42, 55-57.

Oliver, R., \& Mackey, A. (2003). Interactional context and feedback in child ESL classrooms. The Modern Language Journal, 87(4), 519-533.

Oxford, R. L. (2017). Teaching and researching language learning strategies: Self-regulation in context. London, UK: Routledge.

Plonsky, L., \& Brown, D. (2015). Domain definition and search techniques in meta-analyses of L2 research (Or why 18 meta-analyses of feedback have different results). Second Language Research, 31(2), 267-278.

Reinders, H., \& White, C. (2016). 20 years of autonomy and technology: How far have we come and where to next? Language Learning \& Technology, 20(2), 143-154.

Rezaei, S., \& Derakhshan, A. (2011). Investigating recast and metalinguistic feedback in task-based grammar instruction. Journal of Language Teaching and Research, 2(3), 655-663.

Ribeiro, A., Jiang, W., \& Eslami, Z. R. (2019). Corrective feedback in second language face-to-face versus computer-mediated interactions. Language Teaching Research Quarterly, 9(1), 14-30.

Rose, H., Briggs, J. G., Boggs, J. A., Sergio, L., \& Ivanova-Slavianskaia, N. (2018). A systematic review of language learner strategy research in the face of self-regulation. System, 72, 151-163.

Russell, J., \& Spada, N. (2006). The effectiveness of corrective feedback for acquisition of L2 grammar: A metaanalysis of the research. In J. Norris \& L. Ortega (Eds.) Synthesizing research on language learning and teaching (pp. 133-164). Amsterdam: John Benjamins.

Salemi, A., Rabiee, M., \& Ketabi, S. (2012). The effects of explicit/implicit instruction and feedback on the development of Persian EFL learners' pragmatic competence in suggestion structures. Journal of Language Teaching and Research, 3(1), 188-199.

Schulze, M., \& Smith, B. (2015). In theory-We could be better. CALICO Journal, 32(1), i-vi.

Scrivener, J. (2005). Learning teaching: A guidebook for English language teachers. Oxford, UK: MacMillan Education.

Seedhouse, P. (2004). The interactional architecture of the language classroom: A conversation analysis perspective. Malden, MA: Blackwell.

Sheen, Y. (2006). Exploring the relationship between characteristics of recasts and learner uptake. Language Teaching Research, 10(4), 361-392.

Sheen, Y. (2007). The effect of focused written corrective feedback and language aptitude on ESL learners' acquisition of articles. TESOL Quarterly, 41(2), 255-283.

Shintani, N., \& Ellis, R. (2013). The comparative effect of direct written corrective feedback and metalinguistic explanation on learners' explicit and implicit knowledge of the English indefinite article. Journal of Second Language Writing, 22(3), 286-306. 
Shirkhani, S., \& Tajeddin, Z. (2017). Pragmatic corrective feedback in L2 classrooms: investigating EFL teachers' perceptions and instructional practices. Teaching English Language, 11(2), 25-56.

Silva, W. (2018). Autonomous learning support base: Enhancing autonomy in a TEFL undergraduate program. In G. Murray \& T. Lamb (Eds.), Space, place, and autonomy in language learning (pp. 219-232). New York, NY: Routledge.

Storch, N. (2010). Critical feedback on written corrective feedback research. International Journal of English Studies, 10(2), 29-46.

Truscott, J. (1996). The case against grammar correction in L2 writing classes. Language Learning, 46(2), 327-369.

Truscott, J. (1999). The case for "The case against grammar correction in L2 writing classes": A response to Ferris. Journal of Second Language Writing 8(2), 111-122

Ur, P. (1996). A course in language teaching. Cambridge, MA: Cambridge University Press.

Ushioda, E. (2011). Language learning motivation, self and identity: Current theoretical perspectives. Computer Assisted Language Learning, 24(3), 199-210.

Vygotsky, L. S. (1978). Mind in society: The development of higher psychological processes. Cambridge, MA: Harvard University Press.

Yang, Y., \& Lyster, R. (2010). Effects of Form-focused practice and feedback on Chinese EFL learners' acquisition of regular and irregular past tense forms. Studies in Second Language Acquisition, 32(02), 235-263.

Yousefi, M., \& Nassaji, H. (2019). A meta-analysis of the effects of instruction and corrective feedback on L2 pragmatics and the role of moderator variables: Face-to-face vs. computer-mediated instruction. International Journal of Applied Linguistics, 170(2), 277-308.

Zhang, L. J. (2016). A dynamic metacognitive systems perspective on language learner autonomy. In R. Barnard \& J. Li (Eds.), Language learner autonomy: Teachers' beliefs and practices in East Asian contexts (pp. 150-166). Phnom Penh, Cambodia: IDP Education 